\title{
Piotr Skurowski
}

University of Social Sciences and Humanities

Warsaw

\section{Recent Polish Perspectives on U.S. History: A Review Article}

Is there, or can there be, a unique "Polish" perspective on the history of the United States? Perhaps not, if one takes for granted the claims of historiography to scientific objectivity. No truth can be defined by a national point of view - after all, nationality is a construct of the mind, as we're being repeatedly told by social scientists. ${ }^{1}$ Not daring to deny such allegations, one should nonetheless admit that there exists the possibility of a "fresh" perspective on the culture and history of a given country, as taken by outsiders - a perspective understood, primarily, as a different sensitivity due to one's being grounded in a different cultural and historical context. Was it a coincidence, for example, that a pathbreaking study of American racial relations - An American Dilemma (1944) - was authored by a Swedish social scientist?2 (No need to mention Alexis de Tocqueville's De la Démocratie en Amérique, of course). In more recent times, there's compelling evidence that outside perspectives on life, politics and culture in the United States often deserve genuine recognition (if not always granted in the U.S. itself). ${ }^{3}$

The Polish interest in the United States is unflagging. Over the years, the volume of Polish contributions on American life, history and culture has been prodigious. This is no place for giving recognition to what, in this writer's opinion, are the most original Polish "takes" on those topics. One should observe, though, that the Polish interest in the United States is history-conscious and

1 See Benedict Anderson, Imagined Communities. Reflections on the Origin and Spread of Nationalism, New York and London 1983.

2 Gunnar Myrdal, An American Dilemma: The Negro Problem and Modern Democracy, New York 1944.

3 One should give credit here, for example, to such internationally recognized European Americanists as Rob Kroes, Winfried Fluck, or Marc Chenetier. Noted European philosophers, cultural critics and social scientists are often quoted as authoritative commentators on American culture. The list is very long, indeed, and contains such iconic intellectual figures as Herbert George Wells, Theodore Adorno and Johann Huizinga or, more recently, Jean Baudrillard and Umberto Eco. 
culture-specific. There are sound historical reasons for it: in the Polish national imaginary, America has long been constructed as an antithesis to the commonly negative associations made with Poland's next-door neighbours (and, throughout history, also invadors): Germany and Russia. Remote as it is, the United States has usually been perceived in terms of Poland's closest (putative rather than real) ally. The Polish image of the U.S. has long been shaped by the projections of the national desire to secure liberty and independence (the symbolic markers of "America") - hence the commonly uncritical judgments expressed by so many Polish observers of the United States, which often stand in stark contrast with far more critical opinions expressed in other countries. ${ }^{4}$

The Polish historiography on the United States does not necessarily, or at least not as a rule, carry the emotional and ideological baggage implied by the above-mentioned tendencies. ${ }^{5}$ The professional historians who take interest, or specialize in, U.S. history, generally avoid the pitfalls of an idealistic vision of "the land of freedom". Yet the overall tone of this writing has been, on the whole, positive, evidently inspired by a commonly shared respect for the democratic and libertarian ideals inherent in America's political and cultural heritage. One may call it, perhaps, a "Polish perspective", in the sense of this writing often steering clear of revisionist scholarship focused on the darker aspects of American history, including such topics as imperialism, rampant individualism or racial and class inequality. Needless to say, a "Polish" perspective includes special interest in the history of mutual Polish-American relations: political, social (Polish immigration to the U.S.), as well as cultural. ${ }^{6}$

It seems that some of the above-mentioned tendencies provide a common denominator to most of the 24 articles by Polish historians of the United States, assembled in the recently published volume under the promising title Polish Perspectives on American History. Insights, Interpretations, Revisions, edited by Halina Parafianowicz, Professor of American History at Białystok University. ${ }^{7}$

The volume opens with two prefatory articles, one by its editor - Halina Parafianowicz, the other by Kalina Bartnicka, professor at the Institute for the

${ }^{4}$ I'm referring, of course, to the so-called "anti-Americanism", mostly unobserved in Polish academic publications, journalism or in mass media. A peremptory glance at some reading forums, however, leads one to a conclusion that the passions of radical anti-Americanism are not unknown to this country.

5 My comments apply mainly to the post-1989 writing. The Cold War, as long as it lasted, influenced the American historiography in Poland, even though not to the extent one would expect.

6 One should take notice here of the more Left-leaning and "revisionist" approach often preferred by the members of the "alternative" professional Americanist community in Poland, centered around the American Studies programs present at most departments at Foreign Literatures and Languages throughout Poland.

7 Polish Perspectives on American History. Insights, Interpretations, Revisions, ed. by Halina Parafianowicz, Białystok University Press, 2013. 
History of Science, Polish Academy of Science, and wife of the departed Andrzej Bartnicki, the true "founding father" of academic Americanist historiography in post-WWII Poland. Both texts honor the memory of the late Professor Bartnicki, emphasizing his leading role in the launching of American Studies in Poland. Professor Bartnicki's record of accomplishments is impressive indeed, given the fact that most of his academic career took place under the People's Republic of Poland, where for obvious ideological and political reasons (the Cold War, the official anti-American "line" of the ruling communist Polish United Workers' Party) the idea of a close Polish-American academic cooperation necessitated by the American Studies project was, how to put it - risky. Undaunted by the obstacles, Professor Bartnicki took the initiative in the founding of the American Studies Center at the University of Warsaw (the first, and for a long time, only, such academic institution in the Soviet Bloc) and played a key role in forging close academic ties with a number of American universities, including Indiana, Rutgers and and Kent State universities, as well as the University of Kansas (Lawrence) and SUNY at Stony Brook. This network, together with the input from the Fulbright Program allowed to create and maintain close and friendly academic, as well as personal contacts, between the two countries, despite the antagonisms of the Cold War.

But perhaps the most lasting legacy of Professor Andrzej Bartnicki is a generation of Polish Americanists, many of whom consider themselves his disciples. One of them is the editor of the volume in question, professor Halina Parafianowicz, who can be said to be "carrying the torch" of American historiography in Poland today. Another was professor Krzysztof Michałek, first a student and then a close friend of Andrzej Bartnicki, also author of the ambitious and wide-ranging two-volume synthesis of American history: Na drodze ku potędze (On the Road to Power) and Imperium (Empire) whose untimely death terminated an outstanding academic career. It was in fact these two scholars - Halina Parafianowicz and Krzysztof Michałek, who back in 2004 launched the Professor Andrzej Bartnicki Forum for the Advanced Studies of the United States, an annual academic event devoted to the research in American history. Over time, the Forum grew in scope and size, attracting an increasing number of researchers. The publication of the volume under consideration marks the tenth anniversary of the Forum, which makes it evidence of the solidity of the foundations laid by professor Andrzej Bartnicki.

The content of the volume is arranged in chronological order, starting with an article on colonial historiography and ending with several contributions relating to most recent history. The quality of articles published in the volume remains uneven, but the first article in the selection is certainly among its best. In "Alliance Impossible? American Exceptionalism and the New Social History of Early America" professor Irmina Wawrzyczek from Maria Curie-Skłodowska University in Lublin undertook an aptly written synthesis of the historiography of 
colonial North America, focusing on the idea of exceptionalism. As she points out, the notions of American "uniqueness" long tended to dominate the discourse of colonial historians, distorting and marginalizing the role played by such groups as the Amerindians and the Spanish-speaking populations. As long as the "consensus" school was the dominant paradigm, those aspects of American history which were incompatible with the "grand narrative" of American (meaning: white, Anglo-Saxon, Protestant) exceptionalism were mostly downplayed or plainly overlooked. And, since the colonial history seemed to by particularly problematic (too many exceptions from the "exceptionalism" doctrine), it fell into disfavor with American historians, as Irmina Wawrzyczek observes, referring to the relatively inconspicuous body of colonial historiography (compared with writings on later periods) published before the 1960s. The ensuing re-examination of the colonial history strongly disagreed with the claims to its "uniqueness," often emphasizing the extent in which the colonial societies maintained close links with Britain, and consistently adhered to British cultural and political practices and ideas. (Among the best-known representatives of this current is the Polish-educated American historian Michał Rozbicki, co-founder of the Polish Association for American Studies in the 1980s). Yet, as demonstrated by Professor Wawrzyczek, the "new" social history which deconstructed the framework of "exceptionalism," has itself become the target of criticism from those who refuse to abandon the theory of uniqueness altogether - in the last twenty or so years scholars such as Mary Beth Norton and Daniel K. Richter, while insisting on the de-mythologization of the early American history, are nonetheless unwilling to abandon the search for what made the early American history truly unique.

Three more articles in the collection witness to the unceasing appeal of early American history to Polish historians. The first of them (by Jolanta Daszyńska) traces the history of presidential elections from the beginning to 1800 , demonstrating the complex interplay of such crucial factors as the personal popularity and political standing of the candidates, party politics, and the existing Constitutional provisions. Another article, by Katarzyna Stelmasiak, offers a close scrutiny of Thomas Jefferson's letters, written during his diplomatic visit to London in 1786, in which she detects a decisive Anglophobic strain. Finally, Karolina Korytkowska-Ogrodowczyk devoted her article to the history of the founding of Columbus, capital of the state of Ohio, in the years 1802-1816, in which she compares the beginnings of Columbus with that of Washington, D.C. As she points out, the early history of the two capitals - one national, the other a state capital - shows many parallels, but also differences: she perceives the founding of the former as the effect of a political compromise between the Federalists and Democratic Republicans, and that of the latter - as primarily a compromise with a geographical and financial dimension.

Four more articles deal with nineteenth-century American history. Justyna Bartkiewicz-Godlewska devoted hers to Manifest Destiny and its legacy in turn- 
of-the-20 $20^{\text {th }}$-century America, tracing the influence of mid-19 $19^{\text {th }}$ century expansionist ideology on the emergence of new imperial thought and ideology, as reflected in, among others, the writings of Brooks Adams and Alfred T. Mahan. One more author dealing with the turn-of-the-century international politics is Michaf Leśniewski, who wrote on the relations between the United States and the United Kingdom at the time of the Boer War (1899-1902). Leśniewski concludes that, with some notable exceptions (the Irish-American support for the Boers), the war stimulated pro-British attitudes in the United States, particularly representative of the "Anglophile" political elites, while at the same time providing a boost to American economy. In another contribution on 19-th century American history, Lukasz Niewiński takes a close look at the last-minute Southern attempt to reach a compromise with the North, and thus secure sovereign status of the Confederacy. However, the unofficial meeting of the Southern and Northern representatives that took place in Hampton Roads, Virginia, did not produce any results (besides resumption of the exchange of war prisoners), Abraham Lincoln remaining adamant about reincorporating the South into the Union.

The only article in the part of the book dealing with 19th century history that can be said to contain a "Polish" perspective is the one by Anna Stocka concerning the Polish echoes of the 1876 presidential elections, based on her study of a series of contemporary reports written from America by Julian Horain and Sygurd Wiśniowski, and published in the Warsaw newspaper Gazeta Polska. While the Polish correspondences from the U.S. did not seem to show any particular "angle" or bias, their authors' (and, presumably, their readers') interest in domestic American politics was nonetheless remarkable, given the fact that America's international influence (and its potential bearing on the Polish situation) were rather negligible at that time. What seems missing from this article is the absence of context for the above correspondences, by which I mean especially the American visit (featuring a plan to found a utopian community in California) by Poland's best-loved novelist, Henryk Sienkiewicz together with the famous actress Helena Modrzejewska. The fact that Sienkiewicz was also commissioned by Gazeta Polska to write letters from his trip was a strong evidence of increasing interest in America in Eastern Europe. Only a few years later, a combination of "push and pull" factors resulted in a sudden surge in the arrivals of Eastern European immigrants to the United States.

The greater portion of the volume is devoted to $20^{\text {th }}$ century history, with the contributors mainly preoccupied with the international aspects of the U.S. history, mostly political.

I will first focus on those contributions which can be said to contain a "Polish perspective," mainly in the sense of dealing with the U.S. - Polish relations. The most valuable piece is that of Professor Halina Parafianowicz, "Between the Spoils System and Professionalism: U.S. Diplomats in Poland, 1919-1939," the author being one of the the best authorities on the U.S.-Polish relations (and 
a leading Polish historian of the United States). ${ }^{8}$ The article provides portrayals of all the seven successive U.S. envoys and Ambassadors in Warsaw (the first U.S. Envoy being Hugh S. Gibson in 1919, and the first Ambassador - the automotive pioneer John N. Willys in 1930.) Halina Parafianowicz's interest, however, is not narrowly biographical - she suggestively demonstrates how the successive U.S. presidents mostly chose non-career diplomats for the diplomatic post in Poland (with the notable exception of Hugh S. Gibson and, for a brief moment, Ambassador Ferdinand Lammot Belin) - a fact revealing the second-rate status of the post in Warsaw in the view of the U.S. State Department, as well as the continued hold of the spoils system on the U.S. diplomatic appointments. Some details of those postings betray the lack of true professionalism, like the complaints of Ambassador Cudahy who "didn't feel happy in Warsaw and dreamed of a better post, where he could... hunt" (159). John N. Willys, who preceded Cudahy, was also more preoccupied with his automotive business at home than with his mission to Warsaw (157). Regardless of all this, in Halina Parafianowicz's estimate all the American appointees to Warsaw in the interwar period displayed friendly feelings towards Poland, with the last of them, Ambassador Joseph Drexel Biddle, Jr., leaving Warsaw together with the Polish government during the September 1939 campaign, and together crossing the Polish-Rumanian border on September 15.

Another valuable contribution on the U.S.-Polish relations comes from Jakub Tyszkiewicz, writing about the "West-German threat" motif in the antiAmerican communist propaganda in Poland between 1949 and 1989. In his insightful analysis of the political rhetoric in communist Poland Tyszkiewicz demonstrates how, after the founding of West Germany, the Polish propaganda whipped up the fears of "German revenge" insinuating at the same time that the American "imperialists" eagerly supported the alleged West German revanchist schemes by, among other things, rearming the Bundeswehr. Tyszkiewicz discovers that this propaganda strategy was largely dropped in the 1970s, when Edward Gierek replaced Władysław Gomułka as the First Secretary of the ruling Polish communist party. An unexpected reversal occurred in the 1980s, however, when General Wojciech Jaruzelski and his propaganda apparatus revived the Gomulka tactics of using the old scarecrow of the U.S.-West German militarism, particularly after the CDU electoral victory in 1983. Needless to say, such propaganda efforts aimed at legitimizing the Jaruzelski regime and, at the same time, tarnishing the public image of America in Poland, which despite the persistent anti-American propaganda campaigns remained exceptionally positive

8 See, among others, her Polska w europejskiej polityce Stanów Zjednoczonych w okresie prezydentury Herberta C. Hoovera, 1928-1933 (Poland in the U.S. European policy during the presidency of Herbert C. Hoover), Białystok 1991; also, Halina Parafianowicz, Czechosłowacja w polityce Stanów Zjednoczonych w latach 1918-1933 (Czechoslovakia in the U.S. foreign policy, 19181933), Białystok, 1996. 
(more positive, indeed, than in the Western European countries) throughout the Communist period.

In her article, "American Labor Unions' Cooperation with NSZZ Solidarność in the 1980s" Agnieszka Subocz-Gwizdek fills in gaps in the research on the role played by American labor in the Solidarity movement in the 1980s. The financial input on the part of the Lane Kirkland-led AFL-CIO, as demonstrated by SuboczGwizdek, was quite impressive, including direct donations from the main U.S. labor organization, as well as funding by National Endowment for Democracy channeled through the AFL-CIO's Free Trade Union Insitute. Overall the funding made by, or channeled through labor organizations in the U.S. amounted, in the author's estimate, to over $\$ 4$ million dollars, allowing Solidarity to function before the martial law and then to not only survive the military crackdown, but also to triumph in the end. Reading this article one is tempted to speculate whether the assistance from the AFL-CIO and other American institutions was crucial in securing the final victory of Solidarity. While not trying to pose such a question, the author does not even attempt to place the facts in the larger context of American ideology and policies in the Cold War and occasionally demonstrates a rather naive view of things - and, indeed, a shallow knowledge of American history. Commenting, for example, on some formulations in Walesa's Nobel Prize speech in Oslo in 1983, she writes, without any critical afterthought, that " $(\mathrm{T})$ his statement portrays the same two values of the Polish democratic trade union which had been present in the USA from [sic!] 1886: the rights of working people and the dignity of human labor."

The title of Jadwiga Kiwerska's contribution, “America: Poland's Perfect Ally" (the volume's last article) is, fortunately, misleading. Misleading, since it ought to end with a question mark, to better match the content of the article; and fortunately, because the author does not embrace a naive version of idealistic pro-Americanism, as the title inevitably suggests. In fact, the article describes the evolution of the Polish opinion towards the United States between 1989 and the most recent time, from a more or less unqualified enthusiasm for all things American to a far more balanced and increasingly sober perspective of recent time. Kiwerska doesn't fail to mention those factors which seem to have had an influence on this evolution: the growing feeling that Poland's future is tied to the UE rather than to the U.S. (backed by the generous subsidies from the UE); insignificant amount of business with the U.S., as compared with Poland's business with the European countries; opportunities for finding legal employment in the UE (as opposed to the U.S.) and for free travel (again, in contrast with the U.S., where Poles still have to apply for entry visas); a sense of being "used" in the U.S.-led operations in Iraq and Afghanistan without visible recognition (e.g. the visa regulations), financial profits or security gains (the U.S. having so far given up on the deployment of the anti-missile defense shield in Poland). Kiwerska also notices that Poland's standing in the European Union was com- 
promised by the unqualified support given by successive Polish governments to the American interventionist policies - in contradiction of the anti-interventionist views held by Poland's main allies in the UE: France and Germany ("In a way we became less worthy of Europe because we were too pro-American. (...) Thus, we paid a bitter price for our loyalty towards the United States in the European arena, especially in our relations with Paris and Berlin," 353.) Kiwerska is also critical of the "arrogance and disrespect demonstrated by American diplomacy" in Poland, visible particularly during the George W. Bush administration (like in the case of the American offer to deploy the anti-missile defense shield which arrived together with a template for a positive answer). It was the George W. Bush years, in particular, that saw a dramatic reversal in the Polish views on America's international role, which is evidenced in the results of opinion polls: at the beginning of 2007 only $38 \%$ of the Polish respondents positively assessed the U.S. world conduct, in contrast with a similar poll a year before, with $62 \%$ sharing that opinion. In conclusion of her article, Kiwerska identifies with what she believes to be a pragmatic approach to the U.S.-Polish relations demonstrated by the Polish Foreign Minister Radek Sikorski, talking about "cooperation with benefits for both countries."

Finally, a brief overview of the remaining contributions, which do not seem to present any particularly "Polish" perspective on American history, yet are clearly inspired by the writers' interest in its international dimensions. The activities of the Committee on Public Information (CPU) in 1917-1919 in Europe are the subject matter of an article, written by Sylwia Kuźma-Markowska, where the author argues that the unprecedented American propaganda efforts to sway the European opinion in favor of American democracy in the time of WWI and immediately following, were, on the whole, successful, even though the goal of persuading the Bolsheviks to stay in the war was clearly unaccomplished. Interestingly, Kuźma-Markowska demonstrates how the CPU contributed to the legend of Woodrow Wilson being the "savior" of the countries of East-Central Europe. In another article, Mateusz Bogdanowicz talks about American policies in WWII, focusing on the Destroyers for Bases and Lend Lease programs which, he argues, were far less altruistic than they appeared at first glance: Bogdanowicz stresses the selfish interest of the United States in "disassembling" the British Empire and laying the ground for future American world dominance, at the cost of Great Britain. West European - precisely Dutch - anti-Americanism, is the subject matter of Anna Wyrwisz's article, where we can find a discussion of some "classic" anti-American texts by the Dutch writers from the interwar period (Johann Huizinga, Menno ter Brak), followed by observations on the Dutch "antiAmericanism" during the Cold War and at the threshold of the new millennium. The author observes that the anti-American sentiments in Holland were clearly on the rise during the administration of George W. Bush, yet the Dutch have been largely able to express their criticism of the U.S. policies abroad without 
simultaneously embracing a hostile anti-American attitude, as far as their views on American culture and society. Two articles are preoccupied with the U.S. cultural diplomacy and propaganda in the Cold War era. Halina Bieluk writes about the cultural diplomacy efforts, including the active promotion abroad of American jazz, movies and TV productions, the use of radio broadcasting, exhibitions, academic and professional exchanges, as well as American libraries and centers. The article provides an overview of the U.S. efforts in those areas, mostly on the basis of the published studies on those topics. Renata Nowaczewska, in turn, wrote a study of the role of the U.S. Information Agency (USIA) in the making of a "friendly" image of the U.S. abroad. Drawing on the U.S.I.A. documents, Nowaczewska outlines the main projects undertaken by that institution abroad, including the maintenance of libraries, production of films and TV programs, sponsoring art exhibits, visits by American artists, writers and lecturers, as well international academic exchange - pointing out for example that, at least as far as the West European reception was concerned, the American culture-touting administrators of the USIA programs were often dealing with condescension and outright anti-Americanism. Ironically, they were not always getting enough (material) support in their own country - as Nowaczewska rightly observes, because of a lack of long-term financial commitment of Congress and oftentimes competition with the State Department, the USIA "lacked (and at the same time greatly envied) the scope, the independence and the comparably constant high funding of the British Council." One should also agree with her judgment that the incorporation of the USIA into the State Department was a poor decision, from the viewpoint of the effectiveness of American cultural policy.

It is worth noting that as many as four articles are devoted to the the U.S. relations with the Muslim world and the American military intervention in that region, reflecting a growing interest in those topics among the Polish Americanists. Thus Joanna Modrzejewska has written on the U.S.-Afghan diplomatic relations between 1919 and 1942, arguing that, despite some Afghani overtures in the earlier period, only the circumstances of WWII forced the U.S. to take a more keen interest in the affairs of Central Asia, leading to the establishment of American legation in Kabul in 1941. Tomasz Gajewski explores the roots of anti-Americanism in the Middle East, arguing that "modern anti-Americanism was born when people from the Middle East began to perceive Washington's policy as hostile and imperial" but warning at the same time against undue generalizations of that complex relationship. In another contribution, Maciej Huczko analyzes the "challenges and opportunities for the pro-Palestinian lobby in the United States during the intifada years," distinguishing between the first intifada (1987-1993) and the second one (2000-2005). The author describes the difficulties faced by the Palestinian lobby groups in the United States, particularly in the wake of September 11 attacks, also pointing to the influence of such factors as the clash of civilizations theory formulated by Samuel Huntington. Finally, 
Ewelina Waśko-Owsiejczuk discusses the anti-American backlash resulting from the worldwide outrage caused by the media reports on Abu Ghraib and the Guantanamo prison camp, pointing out, among other things, the Bush administration's inconsistency in criticizing other countries on account of their abuse of human rights while at the same time allowing flagrant breaches of such rights by the American military forces in Iraq or Guantanamo.

In conclusion, the volume is a valuable contribution to the U.S. history studies in Poland. A number of articles, consistently with the book's title, provide a "Polish" perspective on American history, in the sense that they focus on the U.S.-Polish political and cultural relations, and draw on sources available to historians only in the Polish language. At the same time, the value of the remaining articles in the volume seems to rest not so much in innovative approaches, but rather in their authors' ability to write effective syntheses on the basis of the already existing literature on their topics. All in all, Polish Perspectives on U.S. History is a publication indispensable to the Polish Americanists, and highly recommended to everyone interested in American history, in Poland as well as abroad. 